\title{
Seawater Cycling Cooling and Its Industrial Application
}

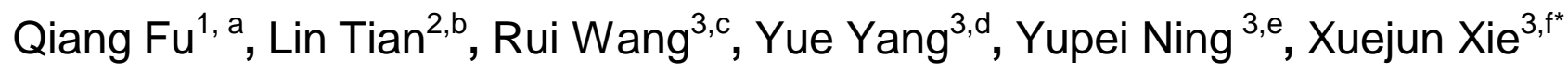 \\ ${ }^{1}$ Guangdong Power Grid Electric Power Science \& Research Institute, Guangzhou, China \\ ${ }^{2}$ Cnooc zhuhai gas power generation co., LTD, China \\ ${ }^{3}$ School of Power and mechanical engineering, Wuhan University, Wuhan, China \\ a 13926402226@163.com, barlyne-tian@qq.com, ${ }^{c} 1193944478 @ q q . c o m,{ }^{d} 405957803 @ q q . c o m$, \\ e2529942777@qq.com, ${ }^{\mathrm{f}}$ xiexuejun@163.com \\ * Correspondent
}

Keywords: List the keywords covered in your paper. These keywords will also be used by the publisher to produce a keyword index.

Abstract. Necessity, history, actuality, problems and countermeasures, industrial application prospect of seawater used as cycling cooling water are analysed. When seawater is used as cycling cooling water, waste water discharge quantity and intake quantity of water are small, engineering investment and operation cost are low, and it is more reasonable in economy. It is in favour of saving fresh water resources, easing tensions in industrial water, protecting marine environment of coastal areas, keeping ecological balance, but the corrosion, scaling and biological control problems in the system running, including salt deposition, salt fog splash, erosion, etc of the seawater cooling tower, should be solved well.

\section{Fresh water resources are short in our country, and seawater need be used as industrial cooling water}

The shortage crisis of fresh water resources has become increasingly worse, and the normal activities of human beings are under serious threat, with the rapid development of social economy, population growth and the increasing deterioration of the ecological environment. Our country is ranked as one of the 13 driest countries in the world by the United Nations, and lack of fresh water resources is one of the most serious resource problems in our country. China's coastline is $1.82 * 10^{3} \mathrm{~km}$, and dozens of coastal cities are rich in seawater resources. ${ }^{[1-4]}$

According to statistics, about $80 \%$ of the urban water is industrial water, and about $80 \%$ of the industrial water is industrial cooling water. In coastal areas, fresh water resource is very limited, and allowable withdrawal is declining year after year. In coastal and island areas, seawater used as source of thermal power, nuclear power, petrochemical, chemical, metallurgical and other industries cooling water, not only can save fresh water, make the limited freshwater resources for maximum use, alleviate contradictory problem of the shortage of fresh water and the industrial development, but also is the important way to solve the shortage of water resources in our country industry, will produce remarkable economic benefit and social benefit. At present, a batch of seawater cooling thermal power plants, nuclear power plants have been set up in China's coastal areas. ${ }^{[4-9]}$

\section{The history and status quo of seawater used as industrial cooling water}

Cooling ways include once-through cooling and cycling cooling when water is used as industrial cooling water.

Once-through cooling using seawater is that seawater is discharged directly after it is pumped through simple grid filters and into the condensers or other heat exchange equipments. At present, the cooling way is adopting by most of coastal thermal power plants, because it has a lot of advantages, including that seawater temperature is low and quite stable, seawater resources are rich, stable and reliable, cooling effect is good, operation and management is simple, water price is low and economic, 
etc. But pipes should be taken into consideration of anti-corrosion measures, such as reasonable selection of materials, coating, cathodic protection and adding chlorine to inhibit sea creatures, because there are serious corrosion, scaling, fouling organism, pollution, large withdrawals and emissions, large investment and other issues.

Cycling cooling using seawater is that seawater is recycled through cooling towers after it is pumped through simple grid filters and into condensers or other heat exchange equipments, and it is formulated on the basis of once-through cooling using seawater and cycling cooling using fresh water. $[4,5,7]$

The technology of using seawater as industrial cooling water abroad has a history of nearly 80 years. More economic and reasonable seawater cycling cooling technology has begin to be researched in the 1970s, and has been applied in the practice now. The first seawater cycling cooling system was built in a certain power plant, Atlantic city, the United States in 1973 , whose seawater flow is $14423 \mathrm{~m}^{3} / \mathrm{h}$, cycling seawater was delt with by adding antiscale, inhibitor, the bacterium and algae biocide, the cooling tower packings were replaced after they were run 20 years or so, and The operation of the cooling system is stable and normal. Afterwards, the seawater cycling cooling technology was applied by a petrochemical enterprise in the United States, the seawater flow is $22000 \mathrm{~m}^{3 /} \mathrm{h}$, the seawater concentration ratio is 1.5-2.5, titanium material was chosen to prevent corrosion in the heat exchanger, and the seawater cooling tower to prevent the salt deposition was designed and manufactured. The seawater cycling cooling technology was applied in the Boyway factory in New Jersey in 1976 by Exxon Research \& Engineering Company and Drew Chemical Company in the United States, the seawater concentration ratio is controlled at 1.5-2.0, automatic system for adding antiscale, inhibitor, bacterium and algae biocide to deal with cycling seawater was applied, whose heat exchanger is clean once half a year. Corrosion situation of carbon steel, copper, navy brass and monel 400 alloy and titanium material, etc. was researched, and corrosion rate of carbon steel, copper, navy brass is respectively $0.15 \mathrm{~mm} / \mathrm{a}, 0.076 \mathrm{~mm} / \mathrm{a}, 0.076 \mathrm{~mm} / \mathrm{a}^{[1,2,4]}$

After 40 years of development, the seawater cycling cooling technology have more practical application in the electric power, chemical industry. The seawater cycling cooling system is used in No.1, 2 of 530 MW combined cycle units of the Morro Bay power plant in California, the United States. The seawater concentration ratio is $2.0 \mathrm{in} \mathrm{New} \mathrm{Jersey.} \mathrm{The} \mathrm{seawater} \mathrm{concentration} \mathrm{ratio} \mathrm{is} \mathrm{controlled} \mathrm{at}$ 1.5 by the Fluor Company in the United States and is applied in Okinawan, Japan. The seawater concentration ratio is controlled at 1.5 and applied in the oil companies, Sweden, Singapore, Kuwait. For economic and environmental considerations, the seawater cycling cooling technology was applied in No.3 of $1100 \mathrm{MW}$ unit of the Hope Creek nuclear power plant in New Jersey, the United States, whose seawater flow is $152000 \mathrm{~m}^{3} / \mathrm{h}$, it is showed that application of seawater cycling cooling technology is toward large-scale development..$^{[4,5,7]}$

It is early in the respect of using directly seawater as industrial cooling water in China's coastal areas cities, but overall development is slow, and only once-through cooling system is applied. Before the 1990s, seawater cycling cooling technology has not yet been applied in our country. Namely, the using of seawater cycling cooling technology in our country began in the 1990s, for Belgium HAMON company counterflow natural ventilation cooling tower calculation program was introduced and calculated in the early $1990 \mathrm{~s}$, and the research of seawater cycling cooling technology began at the same time.

For example, the seawater cycling cooling dynamic simulation experiments was researched by Xian thermal research institute co., LTD. (TPRI) in Tianjin Dagang power plant along the Bohai bay in the early $1990 \mathrm{~s}$. With seawater cycling cooling technology used in the $600 \mathrm{MW}$ and $1000 \mathrm{MW}$ generating set of China's coastal areas, aiming at the system characteristics of the seawater cycling cooling engineering and the related technical requirements of cycling cooling water in thermal power plants, the fouling, bacteria and algae, corrosion control problem of the cycling seawater was researched, the treatment scheme of adding antiscale, inhibitor, bacterium and algae biocide and the technical solutions of seawater cycling cooling system operation and management were proposed by TPRI. 
The seawater cycling cooling technology about corrosion, dirt and bacteria and algae control has been researched by Tianjin institute of seawater desalination and comprehensive utilization, the state oceanic administration, since "the ninth five-year". Through laboratory experiment and pilot, industrialization demonstration project research, the box of water quality standards of the fresh water cycling cooling was broken through, and the goal of seawater instead of fresh water for industrial cycling cooling was achieved. The box of metal material selection standards of the seawater cooling system was broken through, and the goal of seawater cooling water system using ordinary carbon steel was realized. Major breakthroughs have been made in key technologies such as seawater corrosion inhibitor, scale inhibitor dispersing agent, bacterium and algae biocide, corrosion resistant material and seawater cooling tower, and complete sets of processing technology of seawater cycling cooling have been formed initially. ${ }^{[4]}$

\section{The problems and countermeasures of water used as industrial cooling water}

The seawater is a dilute electrolyte solution, whose main ingredients are $\mathrm{Na}^{+} 、 \mathrm{Cl}^{-} 、 \mathrm{Mg}^{2+} 、 \mathrm{Ca}^{2+}$ 、 $\mathrm{K}^{+} 、 \mathrm{HCO}_{3}{ }^{-} 、 \mathrm{SO}_{4}{ }^{2-} 、 \mathrm{Br}^{-}$, etc. Analysis results of seawater samples from different regions in the world show that there is a constant proportion relationship among the main compositions of seawater, the total mass fraction of soluble salt is shifty, the mass fraction of salt in the general seawater is of $3 \%$ to $3.5 \%$ (salt content is $30000-35000 \mathrm{mg} / \mathrm{L}$ ) and the mass fraction of salt in some seawater is of $4 \%$ to $4.5 \%$ (salt content is $40000-45000 \mathrm{mg} / \mathrm{L}$ ). So, salt content of seawater is high, the concentration of corrosion and fouling ions in seawater is considerably higher than that in fresh water, organic matter in seawater is rich, especially organic acids is rich in seawater, there are many types of macroorganism and microorganism and they grow quickly. Therefore, severe corrosion, scaling and fouling organisms adhesion problems are faced when seawater is used as industrial cooling water, and seawater does not conform to cycling cooling water quality requirements stipulated in the national standards "specification for design of industrial cycling cooling water treatment ". [10-12]

More severe problems are faced when seawater is used as industrial cycling cooling water. On one hand, more severe corrosion, scaling and fouling organisms adhesion problems are faced, and seawater need to be filtered with strainer, seawater was delt with by adding seawater corrosion inhibitor, scale inhibitor dispersing agent, bacterium and algae biocide, etc. On the other hand, salt deposition, salt fog splash, erosion, etc of the seawater cooling tower are faced. The corrosion proof requirement of reinforced concrete, supporting structures, the in and out of water pipes, water distribution system, etc of the seawater cooling tower, and the requirement of preventing fouling and plugging of packing are stricter than that of the fresh water cooling tower, It should be considered to prevent the leakage of concrete, adopt anticorrosion coating, use corrosion resistant materials and add seawater corrosion inhibitor, scale inhibitor dispersing agent, bacterium and algae biocide, etc. To mechanical ventilation seawater cooling tower, the influence of coastal salt fog to the components of draught fan, motor and transmission machinery should still be considered. Because on one hand, compared with seawater once-through cooling and fresh water cycling cooling, salt content of seawater and the mass fraction of corrosive and scaling ions are higher after seawater is cycled and concentrated. For example, the seawater cooling tower is adopted in No. 1, 2 of $530 \mathrm{MW}$ combined cycle units of the Morro Bay power plant in the United States, whose mass fraction of cycling seawater is $5 \%$, about 1.5 times that of fresh make-up seawater. On the other hand, there is a seawater cooling tower.

Therefore, the key technology problems of seawater used as industrial cooling water, especially seawater used as cycling cooling water are to solve the severe corrosion, scaling and biological control problems in the system running, including salt deposition, salt fog splash, erosion, etc of the seawater cooling tower, to develop a new type of metal material and coating material to resist seawater corrosion, to research new technology to prevent adhesion of marine organisms, to develop a series of new water treatment chemicals with matching automatic monitoring technology and equipment, such as efficient scale inhibitor dispersing agent, seawater corrosion inhibitor, sea creatures biocide, etc, suitable for different working conditions, a variety of material coexistence system (including stainless 
steel, carbon steel, copper and its alloy, aluminium and its alloy, titanium alloy, etc.). If these problems aren't solved well, seawater will be restricted to be used as cycling cooling water.

At present, by adding seawater corrosion inhibitor, scale inhibitor dispersing agent, bacterium and algae biocide, etc, the technical index requirements stipulated in the relevant national standards can be at or near in the scope of corrosion, scaling and biological control, etc. But there are potential, non-toxic or low toxic, no eutrophication, biodegradation, environmental friendly water treatment agent for seawater cycling water, etc deserves further study.

\section{Industrial application prospect analysis of seawater used as cycling cooling water}

Advantages and disadvantages of seawater used as cycling cooling water. $T$ Compared with seawater once-through cooling and fresh water cycling cooling, it is the advantages of seawater cycling cooling that waste water discharge quantity and intake quantity of water are small, the waste water discharge quantity of seawater cycling cooling decreases more than $95 \%$ than that of seawater once-through cooling, engineering investment and operation cost are low, it is more reasonable in economy, and it is in favour of environmental protection, pollution prevention, keeping ecological balance, because seawater is used circularly. But the water qualty of cycling cooling seawater is worse, and more severe corrosion, scaling and fouling organisms adhesion problems are faced continually, salt deposition, salt fog splash, erosion, etc of the seawater cooling tower are also faced. ${ }^{[7]}$

In favour of saving fresh water resources, easing tensions in industrial water. Because the intake quantity of water of seawater cycling cooling decreases more than $95 \%$ than that of seawater once-through cooling, its intake quantity of water is small, and it is in favour of saving fresh water resources and easing tensions in industrial water. ${ }^{[6,7]}$

Economic benefits of enterprises can be increased when seawater used as cycling cooling water. Because compared with seawater once-through cooling, the intake quantity of water of seawater cycling cooling decreases dramatically, engineering investment and operation cost are low, operation cost of seawater cycling cooling is only $60 \%$ of fresh water cycling coolingand $40 \%$ of seawater once-through cooling. For example, a $600 \mathrm{MW}$ generating unit, whose water flow is about $10^{5} \mathrm{~m}^{3} / \mathrm{h}$ and rate of make-up water is $3^{*} 10^{3} \mathrm{~m}^{3} / \mathrm{h}$ by make-up water percentage of $3 \%$. Water rate of make-up fresh water for a year is $\mathrm{RMB} 4.2 * 10^{5}-1.68 * 10^{6}$ yuan by running time of $7000 \mathrm{~h}$ and water rate of fresh water of RMB 0.02-0.08 yuan/ton if fresh water is used as cycling cooling water, and the cost can be saved if seawater is used as cycling cooling water.

It is in favour of protecting marine environment of coastal areas and keeping ecological balance. Environment problems caused by seawater used as cooling water, are mainly soil salinization problem caused by system leakage, thermal pollution problem caused by a large number of drainage to the sea, destruction of the natural environment caused by building large seawater treatment plant, etc.

Because the intake quantity of water of seawater cycling cooling only takes up $5 \%$ of use of water, decreases $95 \%$ than that of seawater once-through cooling compared with seawater once-through cooling, large tank needn't to be constructed and the natural coast landscape can be kept basicly. the waste water discharge quantity of seawater cycling cooling only takes up $2.5 \%$ of use of water, decreases $97.5 \%$ than that of seawater once-through cooling compared with seawater once-through cooling, thermal pollution problem caused by drainage is no difference between seawater cycling cooling and fresh water cycling cooling. The leakage problem in the process of conveying seawater can be resolved through overall arrangement.

Compared with seawater once-through cooling and fresh water cycling cooling, seawater used as cycling cooling water is advantageous in the scope of economy, environment, etc, is one of the main development direction of seawater cooling.

\section{Conclusions}

Because of the advantages of seawater cycling cooling that waste water discharge quantity and intake quantity of water are small, engineering investment and operation cost are low, it is more reasonable in 
economy, it is in favour of saving fresh water resources, easing tensions in industrial water, protecting marine environment of coastal areas, keeping ecological balance, and fresh water resources in China's coastal areas are seriously short, seawater used as cycling cooling water in the thermal power plants, nuclear power plants in coastal areas, is advantageous in the scope of economy, environment,etc. but the corrosion, scaling and biological control problems in the system running, including salt deposition, salt fog splash, erosion, etc of the seawater cooling tower, should be solved well.

\section{References}

[1] Hongmao Dong, Chemical water design, 1 (1992) 32-34.

[2] Bensheng Zhou, Industrial water treatment technology, Chemical Industry Press, Peking, Patent 95 - 96 (1997).

[3] Yuanyuan Wang, Industrial water treatment, 10(1) (1990) 8 - 10.

[4] Yuzhong Zhang, Xiaomin Peng, Industrial water treatment, 24 (8) (2004) 14 - 17.

[5] Ming Xu, Electric power construction, 23 (5) (2002) 12 - 13.

[6] Chunyang Hou, Jie Wu, Nan Zhao, Yunfang Wu, Shujing Liu, Weizhen Wang, Ocean technology, 21 (4) (2002) 46 - 50.

[7] Chunyan Yang, Yongzhang Zhou, Min Liu, Kaiwei Guo, Ccorrosion \& protection, 32 (7) (2011) $532-534,561$.

[8] Guangzhu Wang, Chengrong Li, Jinde Zhou, Jianghe Luo, Deliang Wang, Kun Fan, Jianhe Ding, Qingjie Ren, Baoqi Chen, Xiaozhong Huang, Thermal Power generation. 11 (2007) 68 - 71.

[9] Chengxin Nie. Water treatment technology. 9 (1) (1982) $34-35$.

[10] Blin F, Leary S G, C. J. Appl. Electro. Chem., 34 (2004) 591.

[11] Blin F, Koutsoukos P, Klepetsianis P, et al. Electrochim. Acta, 52 (2007) 6212.

[12] Rosliza R, Wanik W B, Curr. Appl. Phys., 10(1) (2010) 221. 